\title{
Empirična preveritev obstoja in delovanja notranjih kontrol pri pripravi konsolidirane premoženjiske bilance države in občin v Sloveniji
}

\author{
UDK: 35:336.146(497.4)
}

Jasna Ida Zafred

Urad RS za nadzor proračuna

jasna.zafred@gmail.com

\section{IZVLEČEK}

Uskupinjevalni postopek, $v$ katerem se predstarlja skupina podjetij kot eno samo, je predpisan z mednarodnimi računovodskimi standardi, skladno z njimi pa je bil prevzet tudi $v$ slovenske računovodske standarde in mednarodne standarde za javni sektor. Izvesti ga je mogoče po predhodni pripravi temelinih računovodskih izkazov obvladujočega podjetja in odvisnih podjetij. Iz strokovnih usmeritev izhaja tudi ena od zahtev, da med pobotanimi stanii ne sme prihajati do t. i. nepravih razlik zaradi neurejenega računovodenja.

Čeprav računovodskih izkazov slovenske osebe javnega prava ne pripravljajo na način kot določajo standardi, se uskupinjenje izvaja, vendar le za določene podatke bilanc stanja in na podlagi posebnega predpisa. Ta pa dopušča nastanek razlik pri pobotu terjatev in obveznosti med proračunskimi uporabniki, kar vpliva na stanje splošnega sklada države.

$V$ raziskavi smo $z$ metodo naključnega vzorčenja $z$ uporabo anketne raziskave po komponentah modela COSO empirično preverjali, kako učinkovit je notranjekontrolni sistem pri pripravi izvirnih listin bilanc stanja $v$ slovenskem javnem sektoriu. Ugotovili smo, da so formalnopravno sicer dopustne razlike hkrati tudi neprave razlike, zaradi česar je verodostojnost skupinskega računovodskega izkaza lahko vprašljiva. Preveritev komponente kontrolnega okolja je npr. pokazala, da so zakonski roki za potrjevanje odprtih postavk določeni prehitro, postopek pa ni dovolj natančno dogovorjen, kadar pride pri uskupinjevanju terjatev in obveznosti do razlik. Na kontih kratkoročnih terjatev in obveznosti do proračunskih uporabnikov na dan 31.12. obstajajo stanja,

Zafred, J. I. (2011). Empirična preveritev obstoja in delovanja notranjih kontrol pri pripravi konsolidirane premoženjske bilance države in občin v Sloveniji. 
Jasna Ida Zafred

Empirična preveritev obstoja in delovanja notranjih kontrol pri pripravi

konsolidirane premoženjske bilance države in občin v Sloveniji

kar lahko vodi v tveganja nastanka razlik pri pobotu in za niz kontov smo v komponenti kontrolnih aktivnosti dejansko ugotovili, da proračunskim uporabnikom na dan 31.12. ni uspelo pobotati stani ali stani sploh niso usklajevali, vzroke, zaradi katerih je prišlo do razlik in ukrepe, ki jih v izogib nastanka razlik predlagajo vodje računovodstev. Na vprašanja komponente informiranja in komuniciranja so računovodje odgovorili, da si želijo več izobraževanja, predstojniki pa bi lahko boli uporabljali informacije iz računovodskih izkazov pri svojih odločitvah. Še vedno je programska oprema premalo zaščitena, kajti ponekod se posega $\mathrm{v}$ bazo računovodskih podatkov. Rezultati $v$ komponenti spremljanja pa so pokazali, da revizija postopka priprave premoženjske bilance še marsikje ni bila opravljena.

Ključne besede: uskupinjenje (konsolidacija), model COSO, neprave razlike, naključno vzorčenje, anketna raziskava

JEL: $H 83$

\section{Uvod}

Zaradi večanja razlike med deklarativnimi obljubami politike in dejanskim izvajanjem javnih storitev, financiranih z davkoplačevalskim denarjem, se je javni sektor razvitih držav OECD-ja v zadnjih desetletjih prejšnjega stoletja pri razvijanju meril kakovosti, ekonomičnosti, učinkovitosti izvajanja in preglednosti financiranja javnih storitev začel zgledovati pri zasebnem sektorju. Reforme so $v$ javni sektor vnesle mnoge prakse, sicer uveljavljene $v$ zasebnem sektorju.

Osrednji del reform javnega sektorja je bila tudi sprememba sistema računovodenja. Vse države, ki so izvedle reformo javnega sektorja, so opravile tudi prehod z računovodenja na podlagi denarnega toka na računovodenje na podlagi poslovnih dogodkov.

Odbor za mednarodne računovodske standarde za javni sektor (angl. The International Public Sector Accounting Standards Board) pri Mednarodni zvezi računovodii (angl. International Federation of Accountants - IFAC Board) je razvil visoko kakovostne mednarodne računovodske standarde za javni sektor (angl. International Public Sector Accounting Standards, v nadaljevanju: IPSAS), zlasti zaradi popolnega in kakovostnega računovodskega poročanja. Z IPSAS se dosega konsistentnost in primerliivost računovodskih informacii $v$ različnih pravnih sistemih, zato se vlade in nacionalne institucije, pristojne za izdajanje standardov (angl. national standard-setters), spodbuja, da s svojimi predlogi sodelujejo pri razvoju teh standardov. 
Izdani IPSAS so pripravlieni tako za računovodenje na podlagi denarnega toka kot za računovodenje na podlagi poslovnih dogodkov. Samo na podlagi slednịh je mogoče pripraviti temeljne računovodske izkaze in z njimi popolno uskupinjevanje (konsolidacijo, v nadaljevanju: uskupinjevanje). Osnovna značilnost skupinskega računovodskega izkaza so izločene medsebojne poslovne teriatve in poslovni dolgovi ter medsebojni prihodki in odhodki. Ob pogoju urejenega računovodenja so te vrednosti pri upniku in dolžniku enake, zato pri pobotu ne prihaja do razlik. Lahko so prave, posledica različnih načinov vrednotenja računovodskih postavk, ki smo jih zaradi enotnih predpisov za osebe javnega prava v naši raziskavi izločili. Če so razlike neprave, so posledica pomanjklijvosti v izvajanju računovodske funkcije.

Sistem računovodenja oseb javnega prava $v$ Sloveniji je modificiran, vsebuje značilne postopke enega in drugega sistema računovodenja. Kljub temu se iz določenih podatkov bilanc stanja oseb javnega prava na podlagi posebnega predpisa pripravlja skupinski računovodski izkaz države, konsolidirana ${ }^{1}$ premoženjska bilanca države in občin. Predpis dopušča razlike pri pobotu stani računovodskih postark, ki na zadnji stopnii uskupinjevalnega postopka spreminja knjižno stanje poslovnega sklada države.

$\checkmark$ prispevku smo se osredotočili na naravo dopuščenih napak, ki bi jih moral notranjekontrolni sistem pravočasno odkriti in odpraviti. Uporabili smo model COSO (angl. Committee of Sponsoring Organisations of the Treadway Commission's integrated framework for internal control in s statistično metodo nakliučnega vzorčenja $z$ uporabo anketne raziskave preiskovali posamezne aktivnosti pri evidentiranju poslovnih dogodkov $v$ izvirnih listinah, podlagah za pripravo konsolidirane premoženiske bilance države in občin.

Naš raziskovalni problem je ovrednotiti izhodišča in poiskati odgovor na raziskovalno vprašanje, ali se - ob tem, ko na obravnavanem področju pravila in kriteriii niso povsem jasni in se tudi razmeroma pogosto spreminjajo glede na moč različnih lobijev - nadzornik obnaša družbeno odgovorno in v pretežni meri spoštuje etično-moralne norme in določila pozitivne zakonodaje ter ali so institucije državne uprave s svojim nadzorstvenim aparatom nad delom nadzornikov učinkovite in uspešne.

1 Pravilnik uporablia izraz "konsolidirana" in ne "skupinska", zato bo v prispevku izraz uporabljen le $v$ tej besedni zvezi. 


\section{Teoretične in zakonske podlage za pripravo skupinske (konsolidirane) premoženjske bilance države in občin}

\subsection{Skupinski računovodski izkazi v zasebnem sektorju}

Slovenski računovodski standardi ( $v$ nadaljevanju: SRS), ki temeljiio na mednarodnih računovodskih standardih ( $v$ nadaljevanju: MRS) v uvodu (2006, str. 15) določajo, da je v skupinskih računovodskih izkazih skupina predstavljena, kot da bi šlo za eno samo podjetje. Lahko se pripravljajo v pogojih računovodenja na podlagi poslovnih dogodkov in so sestavljeni iz posamičnih temeljnih računovodskih izkazov uskupinjenih podjetij z ustreznimi uskupinjevalnimi popravki. Skupino sestavljajo:

- obvladujoče podjetje;

- podjetja, odvisna od njega zaradi deleža v kapitalu;

- podjetja, odvisna od njega zaradi prevladujočega vpliva iz drugih razlogov,

sam postopek pa SRS imenujejo "popolno uskupinjenje".

Za izvedbo popolnega uskupinjenja posamičnih računovodskih izkazov je treba zagotoviti:

- uporabo enotnih računovodskih usmeritev za podobne poslovne dogodke;

- praviloma enako predstavljanje postavk v računovodskih izkazih;

- sestavljanje računovodskih izkazov za poslovno leto, ki se praviloma konča z istim dnem;

- metodo prevedbe iz tuje valute.

Z udejanjenjem zahtevanih zagotovil bi se morali resnični in pošteni posamični računovodski izkazi popolno uskupiniti $v$ skupinske računovodske izkaze brez napak. Vendar napake zelo verjetno obstajajo kot razlike $v$ vrednostih. $V$ literaturi so razlike, ki nastanejo pri uskupinjenju terjatev in obveznosti, razdeljene na dve skupini (Vrankar, 1995, str. 9798):

1. Neprave razlike so posledica napak. Izvirajo iz napačnih knjiženi, časovno neusklajenih obračunov poslovnih dogodkov ali časovno različnih knjiženi. „Nepravim razlikam se je mogoče izogniti z dobro organizacijo in uskladitvijo terjatev in obveznosti med podjetji v skupini.»

54 Uprava, letnik IX, 4/2011 
2. Prave razlike niso posledica napak, ampak uporabe različnih načinov vrednotenja sredstev in obveznosti, ki jih je treba spoštovati pri pripravi računovodskih izkazov, ali npr. uporabe različnih deviznih tečajev na dan knjiženja in na dan 31.12.

Če napake obstajajo, potem torej obstajajo $v$ posamičnih računovodskih izkazih, kajti uskupinjenje se običajno izvede s programskim orodjem, računovodske postavke skupinskih računovodskih izkazov pa niso več predmet knjiženja.

\subsection{Temelini in skupinski računovodski izkazi v javnem sektorju}

Tudi IPSAS temeliijo na MRS. Ohranjajo računovodske postopke in izvirni tekst MRS, kadarkoli je to utemeljeno, hkrati pa razvijajo področja, ki $\vee$ MRS niso vsebovana. So strokovne mednarodne rešitve za pripravo računovodskih izkazov oseb javnega prava za dva temelina načina računovodenja:

- na podlagi denarnega toka,

- na podlagi poslovnih dogodkov.

Medtem ko je priprava računovodskih izkazov na podlagi denarnega toka opredeljena $v$ enem samem standardu, nazadnje izdanem $v$ priročniku o IPSAS (Handbook of International Public Sector Accounting Pronouncements, 2011, str. 1450-1574), temelji računovodenje na podlagi poslovnih dogodkov na 31 -ih IPSAS. IPSAS 1 - Predstavljanje računovodskih izkazov (angl. Presentation of Financial Statements). Popolni računovodski izkazi po IPSAS 1 (Handbook of International Public Sector Accounting Pronouncements, 2007, str. 36-37) obsegajo:

1. bilanco stanja;

2. izkaz poslovnega izida;

3. izkaz sprememb v pribitku sredstev/kapitalu;

4. izkaz denarnih tokov;

5. primerjavo proračuna in dejanskih zneskov kot ločen, dodatni računovodski izkaz ali kot stolpec $v$ računovodskih izkazih, kadar oseba javnega prava objavi svoj veljavni proračun;

6. pojasnila, ki vsebujejo pomembne računovodske usmeritve, in druga razlagalna pojasnila. 
Osebe javnega prava, ki vodijo računovodenje na podlagi poslovnih dogodkov in pripravljajo skupinske računovodske izkaze, uporabljajo IPSAS 6 - Skupinski in ločeni računovodski izkazi (angl. Consolidated and Separate Financial Statements). Standard določa postopke, ki jih je treba izvesti pri uskupinjenju (Handbook of International Public Sector Accounting Pronouncements, 2007, str. 198-200) in so s tehničnega vidika enaki kot pri pripravi skupinskih računovodskih izkazov $v$ zasebnem sektoriu.

\subsection{Temeljni in skupinski računovodski izkazi v slovenskem javnem sektorju}

Računovodenje oseb javnega prava $v$ slovenskem javnem sektorju je modificirano. Vsebuje elemente računovodenja na podlagi denarnega toka in na podlagi poslovnih dogodkov. Pravna podlaga priprave računovodskih izkazov oseb javnega prava $\vee$ Sloveniji so zakon o javnih financah ( $v$ nadaljevanju: ZJF) in zakon o računovodstvu ( $v$ nadaljevanju: $Z R)$ ter podzakonski akti, sprejeti na njuni podlagi. ZR $\vee 21$. členu določa, da je letno poročilo sestavljeno iz:

- bilance stanja,

- izkaza prihodkov in odhodkov,

- pojasnil k izkazom ter

- poslovnega poročila.

V slovenskem javnem sektorju se pripravljajo tri vrste skupinskih računovodskih izkazov:

- ministrstvo za finance pripravlja »konsolidirano globalno bilanco javnega financiranja«, ki zajema »konsolidirani tok štirih blagajn javnega financiranja ${ }^{2}{ }^{2}$ med katerimi so izločeni transferni tokovi, njena priprava pa nima izrecne pravne podlage;

- na podlagi evropskega pravnega reda ${ }^{3}$ pripravlja Statistični urad RS dvakrat letno poročilo o primanjkljaju in dolgu države,

2 Štiri blagajne javnega financiranja so: državni proračun, blagajna pokojninskoinvalidskega zavarovanja, blagajna obveznega zdravstvenega zavarovanja in proračuni občin.

3 Temelii na metodologiii ESR 95 oz. priročniku o primanjkliaju in dolgu (angl. ESR 95 Manual on Government Deficit and Debf) ter drugih evropskih pravnih virih, Uredbi Sveta Evrope št. 3605/1993, Uredbi Sveta Evrope št. 475/2000, Uredbi Sveta Evrope št. $2103 / 2005$ in Uredbi Evropske komisije št. 351/2002 (Poročilo o primanjkljaju in dolgu države, 2009). 
v katerem so "polno zajeti vsi prihodki in odhodki vseh institucionalnih enot sektoria država, tudi tistih, ki $v$ bilancah javnega financiranja niso vključene oz. so $v$ njih zajete samo deloma« (Poročilo o primanjkliaju in dolgu države, 2010, str. 20);

- ZJF v 93. členu in ZR v 29. členu določata pripravo konsolidirane premoženjske bilance države in občin, imenovano tudi akt vlade, za pripravo katere je bil sprejet poseben predpis - pravilnik o pripravi konsolidirane premoženjske bilance države in občin.

Formalnopravno je $s$ pravilnikom o pripravi konsolidirane premoženjske bilance države in občin predpisano le uskupinjenje določenih podatkov iz bilanc stanja oseb javnega prava, ${ }^{4}$ ki se vključujejo $\checkmark$ podsektorje centralne države, lokalne uprave in socialnih skladov. V postopku so formalnopravno dopustne razlike. Nastajajo pri uskupinjenju bilančnih postavk med osebami javnega prava znotraj posameznega podsektorja splošnega sektorja države, kakor tudi na ravneh posameznih podsektorjev, ki na zadnji ravni uskupinjevalnega postopka vplivajo na knjiženo stanje splošnega sklada države.

\subsection{Pomen skupinskih računovodskih izkazov v zasebnem in javnem sektorju}

Skupinski računovodski izkazi se enako kot temelini izkazi pripravljajo za splošne namene, ti. za uporabnike, ki ne morejo zahtevati računovodskih informacii za svoje posebne potrebe. Temelini računovodski izkazi, za skupino podjetij oz. oseb javnega prava pa iz njih izvedeni skupinski računovodski izkazi, so namenjeni notranjemu poročanju, poslovodstvu in drugim odločitvenim ravnem tako $v$ zasebnem kot javnem sektorju. Namenjeni so tudi zunanjim uporabnikom, investitorjem, upnikom in drugim poslovnim partnerjem, ki za svoje odločitve potrebujejo tudi informacije iz (skupinskih) bilanc stanja. Vpliv različnih podatkov iz bilanc stanja na odločitve zunanjih uporabnikov so $\mathrm{v}$ zasebnem sektoriu raziskovali npr. Bessete, 2003; Wahlen, 2001; Rele, 1998; Bartov, 2003; Beneish, 1998; Fairfield, Lombardi \& Scott, 2003; Pae, 2005; Thomas \& Zhang, 2002.

4 Poleg terjatev in obveznosti tudi pasivne in aktivne časovne razmejitve, neplačani prihodki in odhodki ter zneski naložb $v$ namensko premoženje z zneski pripadajočih skladov. 
Uporabniki temeljnih računovodskih izkazov subjektov javnega prava, ki predstavljajo po uskupinjenju podsektorjev centralne države, lokalne uprave in socialnih skladov skupinske računovodske izkaze države, so državljani, davkoplačevalci, volivci, politiki, člani nadzornih svetov, delovna telesa državnih organov, ministrstva in organi $v$ sestavi, zbornice in različna združenja, drugi subjekti javnega prava, npr. agencije, komisije, skratka uporabniki, ki imajo svoj interes. Izračunavanje primanjkljaja in dolga države je predvsem $v$ domeni državnih statistik in makroekonomskih analiz, $v$ okolju računovodenja na podlagi poslovnih dogodkov pa je mogoče tudi $\vee$ funkciji javnega računovodstva. Na prehodu stoletja so to novost $v$ javnem sektorju proučevali npr. Matheson, 2002; Hepworth, 2002; Pallot, 2002; Hodque \& Moll, 2001; Allen \& Chan, 2002; Vašiček \& Vašiček, 2000; kasneje pa npr. Broadbent \& Guthrie, 2008; Kelly \& Wanna, 2004; Wilks, 2007; Papenfuß \& Schaefer, 2009; Benito, Brusca \& Montesinos, 2009; Pérez \& LópezHernández.

Skupinske računovodske izkaze $v$ slovenskem zasebnem sektorju nam je približala M. Vrankar (2009), medtem ko o državnih skupinskih računovodskih izkazih lahko beremo le $v$ uradnih poročilih Ministrstva za finance in Računskega sodišča Republike Slovenije.

\subsection{Temeljna teza raziskave}

Postopek uskupinjenja po MRS in IPSAS lahko sledi le izdelanim temeljnim računovodskim izkazom, ki se pripravljajo $v$ pogojih računovodenja na podlagi poslovnih dogodkov. V slovenskem javnem sektorju imamo modificiran način računovodenja, zato ni pričakovati, da bi bila postopka uskupinjenja računovodskih izkazov $v$ različnih sistemih računovodenja primerljiva. Toda, čeprav je postopek uskupinjenja $v$ konsolidirano premoženjsko bilanco države in občin v Sloveniji predpisan, smo menili, da predpis ne more spreminjati načel urejenega knjigovodenja, ki se $v$ uskupinjevalnem postopku za isti posel $v$ isti vrednosti udejanji v izločitvi knjiženih terjatev pri eni in obveznosti pri drugi osebi javnega prava. Na podlagi ene od zahtev uskupinjevalnega postopka, da se ugotovljena stanja, posli, prihodki in odhodki med osebami javnega prava znotraj skupine $v$ celoti izločijo, smo $v$ izhodišče raziskave postavili vprašanje, zakaj nastajajo pri pobotu neprave razlike oz. kako $v$ procesu uskupinjenja bilančnih postavk $v$ konsolidirano premoženjsko bilanco države in občin delujejo notranje kontrole. Postavili 
smo tezo, da uskupinjena stanja, za katera prej ni vzpostavljen kontrolni sistem, ali ta ne razkriva istovetnosti bilančnih postavk, ne zagotavljajo verodostojnega skupinskega računovodskega izkaza.

Z raziskovalno metodo naključnega vzorčenja z uporabo anketne raziskave smo po komponentah modela COSO empirično preverjali, ali obstoječi notranjekontrolni sistem $v$ procesu priprave konsolidirane premoženjske bilance države in občin $\vee$ Sloveniji razkriva istovetnost bilančnih postavk, ki pogojujejo verodostojnost postopka uskupinjevanja. Odgovore na vprašanja zaprtega tipa v vzorcu (n) smo statistično obdelali ter jih ob določeni stopnji tveganja in zanesljivosti ocene interpretirali za celotno populacijo (P). Nato smo z vprašanji odprtega tipa še mnenjsko utemeljili statistični rezultat za določen odgovor.

\section{Empirična preveritev verodostojnosti postopka priprave konsolidirane premoženjske bilance države in občin ${ }^{5}$}

\subsection{Opredelitev populacije}

Ciljna populacija raziskave so bile osebe javnega prava iz priloge $k$ pravilniku o določitvi neposrednih in posrednih uporabnikov državnega in občinskih proračunov, posproteno na dan 31. 12. 2009 in objavljeno na spletni strani Uprave Republike Slovenije za javna plačila (http://www.ujp.gov.si/dokumenti/dokument.asp?id=122). Vključevala je 2.829 oseb javnega prava. Vzorčni okvir anketne populacije so $v$ tej raziskavi bile vse osebe javnega prava z objavljenega seznama Uprave Republike Slovenije za javna plačila, s katerega so bile izločene vse krajevne skupnosti, mestne četrti in upravne enote, skupaj 950 oseb javnega prava ali $34 \%$ ciline populacije. Večino izločenih, sicer identificiranih elementov ni bilo mogoče locirati, če kot lokacijo elementa $\checkmark$ ciljni populaciji pričujoče raziskave označimo javno dostopnost spletnega naslova oseb javnega prava. Neobjavljen spletni naslov osebe javnega prava je zato pomenil neustrezen, prazen element, ki ni pripadal cilini populaciii, (Kalton \& Vehovar, 2001, str. 72), zato teh elementov nismo upoštevali. Pomembna posledica neustreznih elementov je, da se velikost vzorca zmanjša, zato jih je treba vnaprej predvideti, $v$ grobem

5 Podrobneje o tem glej: Zafred, J. I. (2010): Prevzem mednarodnih računovodskih standardov za javni sektor $v$ računovodske izkaze oseb javnega prava - primer Slovenije (doktorska disertacija). Ljubljana: Ekonomska fakulteta. 
oceniti njihov delež, nato pa vzorec ustrezno povečati. Po določitvi vzorčnega okvira je anketirana populacija raziskave vsebovala 1.879 elementov $(N=1879)$.

\subsection{Anketna raziskava}

Odločitev za uporabo anketne raziskave obstoja in delovanja notranjih kontrol $v$ procesu priprave konsolidirane premoženiske bilance države in občin je temeliila predvsem na teh izhodiščih:

1. premoženjske bilance proračunskih uporabnikov niso javno objavljene, zato so težje dosegliive za raziskovalne namene;

2. ankete so bile namenjene $v$ izpolnitev strokovno najboli usposobljeni skupini, tj. vodjem računovodstev, s čimer se je zmanjšalo tveganje neizpolnjenih anket zaradi neznanja;

3. pretežni del vprašani $v$ anketi je bilo mogoče oblikovati kot vprašanja zaprtega tipa, ti. vprašanja, na katera je bilo treba le izbrati enega od ponujenih odgovorov, kar je skrajšalo čas izpolnjevanja anket in čas obdelave rezultatov;

4. anketna raziskava je bila izvedena kot spletna anketa s spletnega naslova http://www.kwiksurveys.com, kar je prispevalo k učinkovitosti izvedbe raziskave, omejitev glede števila vprašani in anketirancev ni bilo, ta pristop pa je zagotavljal tudi neposreden prenos rezultatov $v$ programsko orodje Excell in SPSS ${ }^{6}$ za namene statistične obdelave.

$\checkmark$ anketi je bilo upoštevano dejstvo, da se $v$ premoženjsko bilanco vključujejo podatki iz bilanc stanja proračunskih uporabnikov, zato so bila anketna vprašanja usmerjena predvsem $v$ preverjanje notranjih kontrol, ki zagotavliajo točnost in popolnost $v$ izvirnih listinah.

Večina vprašani je bila zaprtega tipa, pri katerih smo poleg stanj »da« ali "ne" dopustili tudi odgovor "ne vem". "Ne vem" ni možno stanje, ampak informacija, da računovodja nima vedenja o vprašani vsebini. Če bi bil delež teh odgovorov statistično značilen, bi jih ovrednotili posebej.

Statistično smo odgovore na vprašanja obravnavali kot nominalne spremenliivke, pri čemer smo ugotavljali delež stani obravnavane spremenljivke (odstotke celote). Poseben primer nominalnih spremenljivk

6 Podatki so bili obdelani v verziji Office Excell 2003 in v 17. verziii SPSS. 
so t. i. dihotomne spremenliivke, ki imajo le dve stanji, npr. "da" ali "ne", in jima za statistično obdelavo lahko pripišemo številski vrednosti 1 in 0 .

Samo v delu komponente o oceni tvegani smo zahtevali odgovore o stopnii tvegani po velikostni številčni lestvici od 1 - nizko do 3 - visoko, vendar smo tudi te obravnavali kot nominalne spremenljivke, glede na delež posameznih odgovorov.

Zaradi posebnosti pri knjigovodskem evidentiranju poslovnih dogodkov in pogostosti pojavljanja le-teh smo $v$ komponenti kontrolnih aktivnosti poleg vprašani, na katera so odgovarjali vsi anketiranci, oblikovali tudi vprašanja o obstoju sledi za opravljene kontrolne aktivnosti na značilnih kontih treh skupin proračunskih uporabnikov, ki se uskupinijo $\checkmark$ konsolidirano premoženjsko bilanco države in občin: posebej za neposredne proračunske uporabnike, posebej za posredne proračunske uporabnike ter posebej za javne sklade in druge osebe javnega prava, ki imajo premoženje $v$ svoji lasti.

$\checkmark$ raziskavi smo se zadovoliili z 90-odstotno gotovostjo trditev oz. 10 odstotnim faktorjem tveganja. Če smo želeli pri naši populaciji $\mathrm{N}=1879$ doseči želeno širino načrtovanega intervala zaupanja $\Delta p \pm 5 \%$ pri 90 odstotni gotovosti oz. z 10-odstotnim tveganjem, je bila pri najboli neugodni vrednosti deležev odgovorov $v$ vzorcu $p=50 \%$ potrebna zaželena velikost vzorca $n=238$. Vendar pa smo zaradi okoliščin, ki so vplivale na izpolnjevanje ankete, pričakovali velik delež neodgovorjenih anket. Zato smo izračunano želeno število $n=238$ povečali za faktor 4 in ga zaradi poenostavitve izbire zaokrožili na polovico dejanske populacije, $n=940$, anketo pa poslali na vsak drugi spletni naslov oz. element iz vzorčnega okvira.

\subsection{Statistično vrednotenje rezultatov empirične preveritve obstoja in delovanja notranjih kontrol $\mathbf{v}$ procesu priprave konsolidirane premoženjske bilance države in občin v Republiki Sloveniji}

\subsubsection{Odzivnost anketirancev}

Pri pregledu prejetih rezultatov smo iz prejetih 208 odgovorjenih anket izločili odgovore treh anketirancev, ker smo jih ocenili za neverodostojne, tako da smo delali na vzorcu 205 odgovorjenih anket.

Število odgovorov na vprašanja oz. število enot, kot imenujemo vse odgovore enega anketiranca, se je po serijah vprašani, vezanih 
na komponente COSO, zmanjševalo. Na prvi sklop vprašani, ki so se nanašala na kontrolno okolje, so odgovorili vsi, ki so oddali izpolnjeno anketo, ti. vseh 205 anketirancev. V sklopu vprašanj o oceni tveganj je manjkalo 23 odgovorov ali $11 \%$ doseženega vzorca. Število neodgovorjenih vprašanj se je stopnjevalo do zadnjega sklopa vprašani, spremljanja, na katerega ni odgovorilo 69 anketirancev ali dobrih $33 \%$ doseženega vzorca.

\subsubsection{Statistično vrednotenje rezultatov}

Ker je bilo prejetih nekoliko mani odgovorov, $\mathrm{n}=205$, kot smo načrtovali ob najboli neugodni vrednosti deleža za neki odgovor (p) v vzorcu (n), je bila natančnost rezultatov nekoliko slabša od pričakovane. Toda hkrati so rezultati vrednosti deležev posameznih odgovorov (p) v vzorcu (n) pokazali boljšo sliko. Ker so bila že vprašanja postavliena tako, da je bil pričakovan visok delež odgovorov ene vrste (delež "da" ali "ne" nekega odgovora precej večji od $p=50 \%$ ), so bili tudi izmerjeni intervali zaupanja ožji. Želena širina intervala zaupanja $\Delta p= \pm 5,0 \%$ je bila dosežena že pri $p=0,7=70 \%$ in se je $z$ večanjem $p$ še ožila. Ker v izrazu za standardni odklon

$$
s e(p)=\sqrt{ } v(p)=\sqrt{ }\left[(1-f)^{*} p^{*} q /(n-1)\right]
$$

nastopa produkt $p{ }^{*} q$ in je $q=1-p$, dosega enako odstopanje tudi $q$ oz. p, kadar je ta manjši od $50 \%$. Želena širina intervala zaupanja $\Delta p= \pm 5,0 \%$ je bila dosežena tudi pri $p=0,3=30 \%$ in se je $z$ manjšanjem $p$ še ožila.

$\checkmark$ anketni raziskavi smo $v$ okviru komponente kontrolnih aktivnosti določena vprašanja posebej naslavljali na neposredne proračunske uporabnike, posebej na posredne proračunske uporabnike in posebej na javne sklade, ker smo želeli preiskati stanja, značilna za posamične tri skupine. Na vprašanja javnim skladom smo prejeli le tri odgovore in jih zaradi majhnega števila nismo statistično obdelovali. Primerjava širin intervalov zaupanja $\Delta p$ za posamezne skupine znotraj populacije je pokazala, da ima največji vpliv na natančnost statističnega merjenja velikost vzorca, saj je izračunana širina intervala dvakrat širša (10\% pri neposrednih uporabnikih), ko je vzorec štirikrat manjši ( $n=57$ pri neposrednih uporabnikih) $\vee$ primerjavi z $n=205$ na celotnem vzorcu ob istem $\mathrm{p}$. 
Kadar je delež enot z opazovanim stanjem oz. lastnostjo nizek ali kadar imamo na razpolago manjše vzorce, moramo za oceno zanesljivosti določiti še t. i. koeficient variacije (Kalton \& Vehovar, 2001, str. 119-128).

Pri vrednotenju rezultatov anket upoštevamo koeficient variacije kot mero zanesljivosti rezultatov oz. kakovosti vzorčnih ocen. Kalton in Vehovar (2001, str. 127) navajata, da je meja sprejemljive relativne natančnosti postavljena $\mathrm{z}$ vrednostjo koeficienta variacije $\mathrm{cv}(\mathrm{p})<0,05$. Dopustna meja za mnenjske spremenljivke je $c v(p)<0,10$. Pri večjih vrednostih koeficienta variacije moramo ob morebitni objavi takih rezultatov posebej opozoriti na nezanesljivost rezultatov, ko pa koeficient variacije preseže 0,33 , takšnih ocen naj ne bi objavljali.

Velika večina opazovanih odgovorov $v$ naši anketni raziskavi o kontrolnem sistemu $v$ procesu priprave konsolidirane premoženjike bilance države in občin ter istovetnosti bilančnih postavk je dosegala $v$ vzorcu visoke deleže s koeficientom variacije $c v(p)<0,10$. Poleg odgovorov javnih skladov kot posebne skupine znotraj komponente kontrolnih aktivnosti, ki je zaradi majhnosti vzorca nismo statistično obdelovali, so bili manj zanesljivi tudi odgovori na vprašanja, postavljena neposrednim uporabnikom proračuna znotraj te komponente.

\subsection{Rezultati odgovorov po komponentah COSO}

Za vsako dihotomno spremenljivko in njeno komplementarno vrednost, ti. za vsak delež odgovorov "da" in "ne" v vzorcu, smo izračunali širino intervala zaupanja $\Delta p$ in koeficient variacije cv(p). Zbrali smo tudi rezultate odprtega tipa vprašani. Z njimi smo želeli izvedeti mnenja vodij računovodstev o nekai bistvenih vprašanjih oz. smo želeli mnenjsko utemeljiti poprej statistični rezultat za določen odgovor.

$\checkmark$ prispevku predstavljamo samo ključne rezultate za vsako komponento COSO.

\subsubsection{Rezultati odgovorov na vprašanja kontrolnega okolja}

Obstoj notranjih kontrol $v$ kontrolnem okolju smo preverjali z 11 kompleksnimi vprašanji zaprtega tipa. Z zanesliivostjo $c v(p)=0,06$ ob 10-odstotnem tveganju smo potrdili, da od $49 \%$ do $60 \%$ proračunskih uporabnikov, torei polovica, meni, da so zakonsko določeni roki za potrievanje odprtih postavk glede na zaključek poslovnega leta določeni 
prehitro. Z isto zanesliivostjo smo potrdili, da od $47 \%$ do $58 \%$ proračunskih uporabnikov meni, da $v$ primerih, ko stanja terjatev in pripadajočih obveznosti pri drugem proračunskem uporabniku niso potrjena in obstajajo razlike, postopek zakonsko ni dovoli natančno dogovorjen. Z zanesliivostjo $\mathrm{cv}(\mathrm{p})=0,03$ ob isti stopnji tveganja smo potrdili, da je od $83 \%$ do 91 \% proračunskih uporabnikov 31.12. potrjevalo kratkoročna stanja terjatev in obveznosti, kljub temu, da pravne podlage takšnih potrjevanj izrecno ne zahtevajo.

\subsubsection{Rezultati odgovorov na vprašanja ocene tveganj}

Oceno tvegani smo v celoti preverjali z vprašanji zaprtega tipa. Začeli smo s splošnimi vprašanji o registru tvegani, nato pa smo preverjali, ali pri osebi javnega prava obstajajo stanja na kontih, ki se $v$ premoženjski bilanci uskupinijo.

$\mathrm{Ob}$ pritrdilnem odgovoru so anketiranci $v$ nadaljevanju ocenjevali stopnjo tveganosti, da stanje terjatve ne bo enako stanju obveznosti pri drugem proračunskem uporabniku. S temi vprašanji smo želeli dobiti informacijo:

1. na katerih kontih, ki se uskupinijo, največ proračunskih uporabnikov izkazuje stanja;

2. kateri od teh kontov in $v$ kakšnem odstotku je $v$ postopku uskupinjenja izpostavljen drugačni od nizke stopnje tveganosti za nastanek razlik.

Z zanesliivostjo $\mathrm{cv}(\mathrm{p})=0,04$ in ob 10 -odstotnem tveganju smo potrdili, da stanja in s tem tveganja, da stanje na kontu 14 - kratkoročne terjatve do uporabnikov enotnega kontnega načrta ne bo pobotano, obstajajo $v$ razponu od $67 \%$ do $77 \%$ populacije. Z zanesljivostjo $\mathrm{cv}(\mathrm{p})=0,05$ in ob enakem tveganju trditve $\mathrm{pa}$, da $v$ razponu od $63 \%$ do $73 \%$ populacije obstajajo stanja in s tem tveganja tudi na kontu 24 kratkoročne obveznosti do uporabnikov enotnega kontnega načrta ter $\mathrm{v}$ razponu od $55 \%$ do $66 \%$ na kontu 98 - obveznosti za sredstva, prejeta v upravljanje. Kljub temu je $v$ vsakem od teh pritrdilnih odgovorov več kot $40 \%$ anketirancev menilo, da je tveganje nastanka razlike pri pobotu nizko.

\subsubsection{Rezultati odgovorov na vprašanja kontrolnih aktivnosti}

Kontrolne aktivnosti smo preverjali na naslednje načine:

64 Uprava, letnik IX, 4/2011 
1. z vprašanji zaprtega tipa smo vse anketirance spraševali o istovetnosti evidentiranih stanj v kniigovodskih evidencah;

2. z vprašanji odprtega tipa smo spraševali o mnenju računovodii, zakaj v postopku uskupinienja nastajajo napake;

3. z vprašanji zaprtega tipa smo tri značilne skupine anketirancev spraševali o usklajenosti stani znotraj lastnih knjigovodskih evidenc na različnih, značilnih uskupinjenih kontih za posamezne skupine.

Vprašanje, ali je proračunski uporabnik 31.12. izkazoval stanja na določenih kontih, je bilo kontrolno vprašanje. Z 10-odstotnim tveganjem smo $\mathrm{z}$ zanesljivostjo $\mathrm{cv}(\mathrm{p})=0,04$ (ponovno) potrdili, da stanja kratkoročnih terjatev $v$ populaciji obstajajo $v$ razponu od $65 \%$ do $75 \%$, torej pri dveh tretjinah proračunskih uporabnikov, $z$ isto stopnjo zanesljivosti pa, da obstajajo tudi stanja kratkoročnih obveznosti, prav tako pri dveh tretjinah, in sicer $v$ razponu od $64 \%$ do $74 \%$ populacije. Z zanesljivostjo $\mathrm{cv}(\mathrm{p})=0,07$ in ob enakem tveganju smo tudi potrdili obstoj stanj na kontih dolgoročnih obveznosti za sredstva, prejeta $v$ upravljanje, v razponu od $40 \%$ do $50 \%$ populacije.

$Z$ anketo smo nato izvedli serijo vprašanj odprtega tipa.

Proračunske uporabnike smo zaprosili za navedbo kontov, na katerih jim stani 31.12. ni uspelo pobotati. Navedli so:

- splošni sklad za terjatve za sredstva, dana v upravljanje, splošni sklad za finančne naložbe, obveznosti za sredstva, prejeta $v$ upravljanje;

- kratkoročne terjatve do neposrednih uporabnikov državnega proračuna (nevarni prevozi, refundacije za nego, invalidnine);

- kratkoročne obveznosti do neposrednih uporabnikov državnega proračuna;

- druge kratkoročne obveznosti iz poslovanja (obveznosti za boleznine nad 30 dni);

- druge kratkoročne terjatve (terjatve do Davčne uprave RS);

- druge dolgoročne kapitalske naložbe v državi;

- namensko premoženje, preneseno javnim skladom. 
Anketiranci so navedli tudi konte, na katerih proračunski uporabniki sploh niso usklajevali stani $\mathrm{s}$ protistanji pri drugem proračunskem uporabniku, čeprav so bile postavke odprte:

- kratkoročne obveznosti do neposrednih uporabnikov državnega proračuna (vsi podkonti, požarna varnost);

- kratkoročne terjatve do neposrednih uporabnikov državnega proračuna (nevarni prevozi, refundacije za nego, invalidnine);

- druge kratkoročne terjatve (refundacija invalidnin).

Anketirance smo zaprosili za navedbo vzrokov, zaradi katerih je prišlo do razlik $v$ stanjih, ki jim jih ni uspelo uskladiti s protistanji. Navedli so takšne vzroke:

- obrazci za potrjevanje odprtih postavk sploh niso bili poslani partnerjem ali so bili potrieni napačno (napačna navedba šifer in kontov);

- ni urejena npr. delitev premoženja med novonastalo in bivšo občino;

- proračunski uporabniki nimajo evidentiranih začetnih bilančnih stanj;

- neposredni uporabniki npr. nimajo evidentiranih obveznosti do občine;

- neposredni uporabniki evidentirajo poslovne dogodke $v$ preteklo proračunsko obdobje, čeprav so nastali po 31. 12.;

- pogosta uporaba napačnih kontov;

- prepozno izdelani računovodski izkazi;

- dokumenti niso knjiženi, predvsem tožbene obveznosti, terjatve pri drugem proračunskem uporabniku pa imajo stanja;

- na kontih terjatev niso vključeni obresti in predujmi;

- roki za usklajevanje stanj so prekratki.

Nato smo anketirance zaprosili za navedbo ukrepov, ki bi jih bilo po njihovem mnenju treba uvesti, da do razlik $v$ uskupinjenju med terjatvami in obveznostmi ne bi prihajalo. Predlagali so naslednje ukrepe:

- večkrat letno usklajevanje terjatev in obveznosti, obvezno že 31. 10., predhodno telefonsko usklajevanje stani; 
- uskladitev aktivnosti, ki se vežejo na zaključek proračunskega leta - pravočasno izdajanje računov, časovno enotna obravnava proračunskega leta, dosledno evidentiranje poslovnih dogodkov v leto nastanka poslovnega dogodka, priprava enotnega navodila za knjiženje poslovnih dogodkov ob koncu proračunskega leta;

- obvezna navedba kontov in šifer proračunskih uporabnikov na obrazce potrjevanja stanj;

- na dokumentih proračunskih uporabnikov, ki se vključujejo v premoženjsko bilanco, obvezna navedba šifer partnerjev;

- večja natančnost dela odgovornih oseb;

- jasna in kratka navodila za pripravo premoženjske bilance.

Razlika v postopku uskupinjenja oz. pobota stanj, zaradi česar mora proračunski uporabnik $v$ skladu s pravilnikom o pripravi premoženjske bilance države in občin $v$ svoji premoženjski bilanci povečati vir - bodisi obveznosti za sredstva, prejeta $v$ upravljanje, bodisi splošni sklad, bodisi sklad premoženja $\vee$ javnih skladih, bodisi sklad premoženja $\vee$ drugih osebah javnega prava, ki je $\vee$ nijhovi lasti, lahko nastane kot razlika pri pobotu:

- terjater in obveznosti pri proračunskih uporabnikih, ki imata medsebojna dolžniško-upniška razmerja;

- aktivnih in pasivnih časovnih razmejitev;

- neplačanih prihodkov in neplačanih odhodkov.

Anketirance smo vprašali, ali je pri nijh katera od teh razlik nastala, in če, ali imajo ločeno izkazano sled, kateri vir se je povečal in za koliko. Z zanesliivostjo $\mathrm{cv}(\mathrm{p})=0,07$ in ob 10-odstotnem tveganju smo na podlagi odgovorov potrdili, da razlika $\vee$ pobotu pri proračunskih uporabnikih obstaja $\vee$ razponu od $40 \%$ do $50 \%$ populacije, torei pri polovici proračunskih uporabnikov. Pri koeficientu variacije $\operatorname{cv}(p)=0,10$ in enakem intervalu zaupanja pa lahko trdimo, da obstoj sledi o povečanju virov zaradi razlik v pobotu zagotavlja le od $26 \%$ do $36 \%$ populacije.

Z vprašanji znotraj kontrolnih aktivnosti, naslovljenimi trem najboli množičnim skupinam proračunskih uporabnikov, ki uskupinijo podatke iz bilanc stanja $v$ konsolidirano premoženjsko bilanco države in občin, smo preiskovali predvsem obstoj kontrol v njihovih lastnih knjigovodstvih, ki bi morale zagotavljati usklajenosti stanj med posameznimi konti in protikonti. Za skupino javnih skladov nismo prejeli dovolj odgovorov in je nismo 
statistično obdelovali. Vzorec neposrednih proračunskih uporabnikov je štel le 57 enot, od katerih v poprečju $36 \%$ anketirancev te skupine na vprašanja ni odgovarjalo, zato je koeficient variacije $\mathrm{cv}(\mathrm{p}) \geq 0,10$, odgovori pa so nezanesliivi. Zaradi ugodnejših statističnih parametrov so boli zanesljivi odgovori posrednih proračunskih uporabnikov. Ti praviloma potriujejo usklajenost stani parnih kontov znotraj lastnih knjigovodstev.

\subsubsection{Rezultati odgovorov na vprašanja informiranja in komuniciranja}

Vprašanja informiranja in komuniciranja so bila namenjena ponovno vsem anketirancem, na vprašanja pa ni odgovarjalo med 66 enotami ali 32-odstotnim deležem anketirancev in 68 enotami ali 33-odstotnim deležem anketirancev. Z zanesljivostjo $\mathrm{cv}(\mathrm{p})=0,09$ ob 10-odstotnem tveganju so rezultati ankete pokazali, da med 30- in 41-odstotnim deležem populacije, torej pri eni tretjini proračunskih uporabnikov, programska oprema omogoča spreminjanje že knjiženih podatkov $v$ bilancah stanja, ti. poseganje $\vee$ bazo podatkov. Z zanesljivostjo $\mathrm{cv}(\mathrm{p})=$ 0,07 ob enakem tveganju smo potrdili, da vodstva proračunskih uporabnikov med 39- in 49-odstotnim deležem populacije računovodska periodična poročila uporabljajo pri svojih odločitvah, vendar pa smo s koeficientom variacije $\mathrm{cv}(\mathrm{p})=0,08$ in ob enaki stopnji tveganja tudi potrdili, da več kot tretjina, med 33- in 44-odstotnim deležem poslovodstev, pri svojih odločitvah informacij iz premoženjskih bilanc ne uporablja. Ob tem je bilo ob enaki stopnji zanesljivosti zgovorno mnenje računovodij $\vee$ razponu od $37 \%$ do $43 \%$ deleža populacije, da izobraževanja, ki jih za računovodje proračunskih uporabnikov pripravlja pristojno ministrstvo, niso bila dovoli pogosta.

\subsubsection{Rezultati odgovorov na vprašanja spremljanja}

Komponento spremljanja smo preverjali s štirimi vprašanji. Na to serijo vprašani ni odgovarjalo 69 ali $34 \%$ anketirancev. Z zanesljivostio $\mathrm{cv}(\mathrm{p})=0,07$ in z 90-odstotno gotovostjo smo potrdili, da je bila notranja revizija računovodske funkcije opravljena pri proračunskih uporabnikih v razponu od $40 \%$ do $51 \%$ populacije, z enako stopnjo zanesliivosti pa tudi, da se $v$ razponu med $39 \%$ in $50 \%$ deleža populacije proračunskih uporabnikov predstojnik $v$ zadnjem letu pri pripravljavcih premoženjskih bilanc ni pozanimal o morebitnih težavah, ki jih imajo. Revizija postopka priprave premoženjske bilance zagotovo ni bila opravljena pri polovici proračunskih uporabnikov, $v$ razponu med 47 - in 58-odstotnim deležem 
populacije, kar smo potrdili z zaneslijivostjo $\mathrm{cv}(\mathrm{p})=0,06$ in $\mathrm{z} 10$ odstotnim tveganjem.

\subsection{Zaključne ugotovitve}

Domnevali smo, da so razlike, ki vplivajo na knjigovodsko stanje splošnega sklada države $v$ slovenski konsolidirani premoženjski bilanci države in občin, neprave, posledica slabosti $v$ izvajanju računovodske funkcije oseb javnega prava, kar vpliva na verodostojnost izkazanih podatkov $v$ bilanci. Domnevo smo preizkusili s statistično metodo naključnega vzorčenja $z$ uporabo anketne raziskave $v$ okviru komponent COSO v procesu priprave konsolidirane premoženjske bilance države in občin. Za vsako posamezno komponento COSO smo na vzorcu statistične populacije oseb javnega prava ob 90-odstotni gotovosti oz. 10-odstotnem tveganju prenesli odgovore, večinoma dihotomne spremenljivke, na celotno populacijo in jih interpretirali $v$ izračunanih intervalih zaupanja ob izmerjeni meri zanesljivosti. Postavljeno tezo, da uskupiniena stanja, za katera prej ni vzpostavlien kontrolni sistem, ali ta ne razkriva istovetnosti bilančnih postavk, ne zagotavljajo verodostojnega skupinskega računovodskega izkaza, smo z našo raziskavo potrdili. Potrdili smo obstoj nepravih razlik $v$ uskupinjevalnem postopku priprave konsolidirane premoženjske bilance države in občin, z vprašanji odprtega tipa izvedeli tudi za vzroke nastanka nepravih razlik in za mnenja o ukrepih za odpravo, kot jih vidijo vodje računovodstev. Za zagotavljanje resnične in poštene konsolidirane premoženjske bilance države in občin, ti. verodostojno izkazanih uskupinjenih stani premoženja na ravni države, bo treba uvesti in vzdrževati, predvsem pri pripravi izvirnih listin bilanc stanja proračunskih uporabnikov, notranjekontrolne mehanizme.

Dr. Jasna Ida Zafred je diplomirala na Ekonomski fakulteti v Mariboru in na Višji pravni šoli v Mariboru ter doktorirala na Ekonomski fakulteti v Ljubljani. Pridobila je certifikat pooblaščene revizorke, preizkušene davčnice, preizkušene državne notranje revizorke. Delala je kot davčna inšpektorica, kot revizorka Računskega sodišča RS, kot vodja službe za notranjo revizijo na Univerzi v Mariboru. Od leta 2006 je zaposlena kot državna notranja revizorka na Ministrstvu za finance, na Uradu RS za nadzor proračuna. Ima objavljenih več kot 20 različnih strokovnih člankov in del s področja računovodstva in revizije. 
Jasna Ida Zafred

Empirična preveritev obstoja in delovanja notranjih kontrol pri pripravi

konsolidirane premoženjske bilance države in občin v Sloveniji

\section{Literatura in viri}

- Allen, T. L., \& Chan, J. L. (2002). Public Accountability and Government Financial Reporting: Models of Public Budgeting and Accounting Reform. OECD Journal on Budgeting 2(1), 12-36.

- Bartov, E. (2003). Discussion of "Investor Sophistication and the Mispricing of Accruals". Review of Accounting Studies 8(2/3), 277-281.

- Beneish, M. D. (1998). Discussion of "Are Accruals during Initial Public Offerings Opportunistic?". Review of Accounting Studies 3(1/2), 209-221.

- Benito, B., Brusca, I. \& Montesinos, V. (2007). The harmonization of government financial information systems: the role of the IPSASs. International Review of Administrative Sciences 73(2), 293-317.

- Bessette Russell, W. (2003). Measuring the Economic Impact of UniversityBased Research. Journal of Technology Transfer 28(3/4), 355-361.

- Broadbent, J. \& Guthrie, J. (2008). Public sector to public services: 20 years of "contextual" accounting research. Accounting, Auditing \& Accountability Journal 21 (2), 129-169.

- Bronstein, I. N., Semedjajew, K. A., Musiol, G. \& Mühling, H. (1997). Matematični priročnik. Ljubljana: Tehniška založba Slovenije.

- Fairfield, P. M., Scott, W., Lombardi, T. Y., Whisenant, S. \& Yohn, T. L. (2003). The Differential Persistence of Accruals and Cash Flows for Future Operating Income versus Future Profitability. Review of Accounting Studies 8(2-3), 221-243.

- Hepworth, N. (2002). Government Budgeting and Accounting Reform in the United Kingdom: Models of Public Budgeting and Accounting Reform. OECD Journal on Budgeting 2(1), 116-161.

- Hoque, Z. \& Moll, J. (2001). Public Sector Reform: Implications for Accounting, Accountability and Performance of State-owned Entities: An Australian Perspective. The International Journal of Public Sector Management 14(4), 304-326.

- International Public Sector Accounting Standards Board (2007, februar). IPSAS (2007) Handbook of International Public Sector Accounting Pronouncements. New York: IFAC, International Public Sector Accounting Standards Board (online version). Pridoblieno 14. 8. 2007, s http://www.ifac.org/Members/Pubs-Details.tmplePubID= $11726065236097226 \&$ Category=Public\%20Sector\%20Accounting

- International Public Sector Accounting Standards Board (2011, april). IPSAS (2011) Handbook of International Public Sector Accounting

Pronouncements. New York: IFAC, International Public Sector Accounting 
Standards Board (online version). Pridoblieno 29. 7. 2011 , s http://web.ifac.org/publication

- Jurišič, A. \& Batageli, V. (b.l.). Verjetnostni račun in statistika. Pridoblieno 20. 6. 2010, s http://212.235.189.46/ajurisic/viso8/folije/3x2vs13-14.pdf

- Kalton, G. \& Vehovar, V. (2001). Vzorčenje v anketah. Ljubljana: Fakulteta za družbene vede.

- Kelly, J. \& Wanna, J. (2004). Crashing through with Accrual-Output Price Budgeting in Australia: Technical Adjustment or a New Way of Doing Business? The American Review of Public Administration 34(1), 94-1 11.

- Matheson, A. (2002). Better Public Sestor Governance. The Rationale for Budgeting and Accounting Reform in Western Nations. Models of Public Budgeting and Accounting Reform. OECD Journal on Budgeting 2(1), 3849. Paris: OECD - Organisation for Economic Co-operation and Development.

- Ministrstvo Republike Slovenije za finance (2009, 24. junii). Konsolidirana premoženiska bilanca države in občin na dan 31. 12. 2008. Ljubljana: Ministrstvo za finance. Pridoblieno 3. 9. 2009, s http://www.mf.gov.si/slov/gl-kni-zakl/konsol_bil_2008.pdf

- Navodilo o pripravi zaključnega računa državnega in občinskega proračuna ter metodologije za pripravo poročila o doseženih ciljih in rezultatih neposrednih in posrednih uporabnikov proračuna. Uradni list RS št. $12 / 2001,10 / 2006$ in 8/2007.

- Pae, J. (2005). Expected Accrual Models: The Impact of Operating Cash Flows and Reversals of Accruals. Review of Quantitative Finance and Accounting 24(1), 5-22.

- Pallot, J. (2002). Government Accounting and Budgeting Reform in New Zealand: Models of Public Budgeting and Accounting Reform. OECD Journal on Budgeting 2(1), 164-186.

- PapenfuB, U. \& Schaefer, C. (2009). Public financial reporting in true and fair terms - discussion on shortfalls in Germany and recommendations for the reform agenda. International Review of Administrative Sciences 75(4), 715-725.

- Pérez, C. C. \& López-Hernández, A. M. (2009). Governmental financial transparency in MERCOSUR member countries. International Review of Administrative Sciences 75(1), 169-181.

- Pravilnik o enotnem kontnem načrtu za proračun, proračunske uporabnike in druge osebe javnega prava. Uradni list RS št. 54/2002, 117/2002, 58/2003, 134/2003, 34/2004, 75/2004, 117/2004, 141/2004, $117 / 2005,138 / 2006,120 / 2007,124 / 2008$ oz. 112/2009. 
Jasna Ida Zafred

Empirična preveritev obstoja in delovanja notraniih kontrol pri pripravi

konsolidirane premoženjske bilance države in občin v Sloveniji

- Pravilnik o določitvi neposrednih in posrednih uporabnikov državnega in občinskih proračunov. Uradni list RS št. 46/2003.

- Pravilnik o pripravi konsolidirane premoženjske bilance države in občin. Uradni list RS št. 26/2003, 117/2005, 120/2007, 32/2008, 10/2009.

- Pravilnik o sestavljanju letnih poročil za proračun, proračunske uporabnike in druge osebe javnega prava. Uradni list RS št. 115/2002, 21/2003, 134/2003, 126/2004, 120/2007, 124/2008.

- Pravilnik o razčlenjevanju in merjenju prihodkov in odhodkov pravnih oseb javnega prava. Uradni list RS št. 134/2003, 34/2004, 13/2005, 138/2006, 120/2007, 112/2009.

- Smernice za standarde notranjega kontroliranja za javni sektor (2005). Ljubljana: Slovenski inštitut za revizijo.

- Thomas, J. K. \& Zhang, H. (2002). Inventory Changes and Future Returns. Review of Accounting Studies 7(2/3), 163-187.

- Vašiček, V. \& Vašiček, D. (2000). Razvoj Međunarodnih računovodstvenih standarda za javni (proračunski) sektor. Računovodstvo i financije (1 1), 33 43.

- Vrankar, M. (2009). Skupinski računovodski izkazi. Revija IKS XXXVI(1-2), 182-218.

- Wahlen, J. M. (2001). Discussion of: "Do Stock Prices of Property Casualty Insurers Fully Reflect Information About Earnings, Accruals, Cash Flow and Development?" Review of Accounting Studies 6(2/3), 221-228.

- Wilks, S. (2007). Boardization and Corporate Governance in the UK as a Response to Depoliticization and Failing Accountability. Public Policy and Administration 22 (4), 443-460.

- Zafred, J. I. (2010): Prevzem mednarodnih računovodskih standardov za javni sektor v računovodske izkaze oseb javnega prava - primer Slovenije (doktorska disertacija). Ljublijana: Ekonomska fakulteta.

- Zakon o javnih financah. Uradni list RS št. 79/1999, 124/2000, 79/2001, 30/2002, 56/2002-ZJU, 1 10/2002, 127/2006-ZJZP, 14/2007-ZSPDPO, $109 / 2008,49 / 2009$.

- Zakon o računovodstvu. Uradni list RS št. 23/1999, 30/2002, 114/2006. 